\title{
Tradisi Ampa Sabae dalam Proses Perkawinan Masyarakat Muslim di Desa Nipa Kecamatan Ambalawi Kabupaten Bima (Perspektif Sosiologi Hukum)
}

\author{
Elpipit \\ Universitas Islam Negeri Sunan Kalijaga Yogyakarta \\ elpipitpipit@gmail.com \\ Ama Fitariam Safitri \\ Universitas Islam Negeri Sunan Kalijaga Yogyakarta \\ amafitariam@gmail.com
}

\begin{abstract}
This article discusses the tradition of marriage of the Muslim people of Mbojo/Bima tribe which is reviewed through normative approach and sociology of the law with the aim of revealing a truth over the social reality of a phenomenon of the tradition of "ampa sabae" or the demand to marry by women who are thriving among the people of Bima West Nusa Tenggara. This study is qualitative, free from variable numbers or amounts. The data sources used are primary and secondary data sources. Data collection is conducted with interviews, observations and documentation.The results of this study show that the tradition of ampa sabae (the demand to marry by women, is a tradition or customs that has long developed and lived together with the civilization of ambalaw society, a tradition that originated from this ancestor until now is still preserved by the Ambalawi community a solution for women to hold men accountable if they get bad deeds and feel harmed themselves. In the sociological view of the law there are pros and cons, some consider it good and some consider it not good, each individual society has different assumptions, because it is always associated with the causative factors of the marriage of ampa sabae.
\end{abstract}

Keywords : Tradition, Ampa Sabae, Marriage, Bima

\begin{abstract}
Abstrak
Artikel ini membahas tentang tradisi perkawinan masyarakat muslim suku Mbojo/Bima yang dikaji melalui pendekatan normatif dan sosiologi hukum dengan tujuan untuk mengungkapkan suatu kebenaran atas realitas sosial dari sebuah fenomena tradisi "ampa sabae" atau permintaan menikah oleh perempuan yang berkembang dikalangan masyarakat Bima Nusa Tenggara Barat. Penelitian ini bersifat kualitatif, terbebas dari variabel angka atau jumlah. Sumber data yang digunakan adalah sumber data primer dan sekunder. Pengumpulan data dilakukan dengan wawancara, observasi dan dokumentasi. Hasil penelitian ini menunjukan bahwa tradisi ampa sabae (permintaan menikah oleh perempuan, merupakan suatu tradisi atau adat istiadat yang sudah lama berkembang dan hidup bersama dengan peradaban masyarakat Ambalawi, tradisi yang berasal dari nenek moyang ini sampai sekarang masih dilestarikan oleh masyarakat Ambalawi sebagai solusi bagi wanita untuk meminta pertanggungjawabkan terhadap laki-laki apabila mendapatkan perbuatan yang tidak baik dan dirasa merugikan dirinya. Dalam pandangan sosiologi hukum terjadi pro dan kontra, sebagian ada yang menganggap baik dan sebagian ada yang menganggap tidak baik, masing-masing individu masyarakat mempunyai asumsi yang berbeda-beda, karena selalu dikaitkan dengan faktor penyebab dari pernikahan ampa sabae itu sendiri.
\end{abstract}

Kata Kunci: Tradisi, Ampa Sabae, Pernikahan, Bima 


\section{A. PENDAHULUAN}

Tradisi pada mulanya berasal dari ajaran dan kebiasaan nenek moyang yang diwariskan kepada anak cucunya dalam bentuk sikap, cara berpikir dan cara bertindak secara turun temurun dari generasi kegenerasi dengan berpegang teguh pada norma yang disepakati bersama oleh pembentukannya dalam suatu komunitas masyarakat tertentu ${ }^{1}$. Begitupun dengan adanya praktek tradisi dalam kehidupan masyarakat, seiring berjalanya waktu lalu tradisi ini terbentuk menjadi sebuah kebudayaan, kebudayaan yang berawal dari perilaku dan interaksi masyarakat itu sendiri. ${ }^{2}$ Dalam sosiologi, konsep kebudayaan (culture) sangatlah penting, karena obyek studi pokok sosiologi adalah masyarakat, yang mana masyarakat tidak dapat dipisahkan atau dilepaskan dari kebudayaan. Sebagaimana menurut Horton dan Hun bahwa masyarakat merupakan suatu organisasi menusia yang saling berhubungan satu sama lainya dengan sistem norma dan nilai yang terorganisasi menjadi pegangan. ${ }^{3}$

Dalam konteks sosiologi, perkawinan merupakan bagian dari kebudayaan, karena perkawinan menjadi salah satu sendi kehidpuan masyarakat yang tidak bisa terlepas dari adat kebiasaan atau tradisi yang dimodifikasi oleh sekelompok masyarakat agar sesuai dengan ajaran agama. ${ }^{4}$ Pada ranah kehidupan sosial perkawinan merupakan peristiwa penting bagi kehidupan pribadi setiap orang. Selain untuk menjalankan perintah Allah SWT juga mengikuti sunnah Rasulullah Saw, perkawinan merupakan jembatan yang akan melahirkan generasi penerus zaman dan kebudayaan ${ }^{5}$.

Eksistensi perkawinan masyarakat Indonesia diatur dalam sistem perundang-undangan ${ }^{6}$. Akan tetapi, perkawinan dalam praktiknya terjadi

${ }^{1}$ Sainun, Tradisi Merari', (Mataram: IAIN Matram, 2016), 17.

${ }^{2}$ Menurut Berger dan Luckman dalam bukunya mejenlaskan bahwa pada kenyataanya realitas sosial tidak berdiri sendiri tanpa kehadiran individu, baik di dalamnya maupun di luar realitas tersebut, leih lanjut baca buku, M. Burhan Bungin, Konstruksi Sosial Media Masa, (Jakarta: Pernadamedia Group, 2015), 14.

${ }^{3}$ Ramdan Wagianto, "Tradisi Kawin Colong Pada Masyarakat Osing Banyuwangi Perspektif Sosiologi Hukum Islam”, Jurnal Al-Ahwal, Vol. 10, No. 1, (2017), 61.

4 Ahmad Pattiroy dan Idrus Salam, "Tradisi Doi 'Menre' dalam Pernikahan Adat Bugis Jambi”, Jurna: Al-Ahwal, Vol. 1, No, 1 (2008), 90.

${ }^{5}$ Imam Budhi Santoso, Petuah-Petuah Bijak Para Leluhur Seputar Perkawinan, (Yogyakarta: Laksana, 2011), 5.

${ }^{6}$ Undang-undang yang dimaksud disini adalah Undang-Undang No. 1 Tahun 1974 Tentang Perkawinan, PP No. 9 Tahun 1975 Tentang Pelaksanaan UU No. 1 Tahun 1974, serta Kompilasi Hukum Islam, (KHI) 
persimpangan di masyarakat. Hal ini dikarenakan faktor kemajemukan atau multicultural adat atau tradisi dalam perkawinan di Negara ini. Sehingga terjadi dualisme hukum di masyarakat yang keduanya mempunyai sisi perbedaan ${ }^{7}$, termasuk dalam kemajuan tradisi masyarakat Bima yang ada di Desa Nipa Kecamatan Ambalawi yang melestarikan adat tradisi ampa sabae.

Tradisi ampa sabae merupakan adat kebiasaan yang dilakukan oleh masyarakat Ambalawi sebagai upaya untuk memberikan perlindungan terhadap wanita yang mendapatkan perlakuan yang tidak senonoh dari laki-laki seperti adanya perlakuan pelecehan hingga kehamilan. Tradisi ini dilakukan dengan tujuan untuk menutupi aib perempuan, karena dengan jalan ampa sabae akan mempermudah pihak perempuan untuk meminta pertanggungjawaban terhadap laki-laki, dengan kata lain ini merupakan solusi atau jalan keluar jika pihak laki-laki tidak mau bertanggungjawab atas perbuatanya

Pada pelaksanaanya pernikahan yang dilakukan dengan cara ampa sabae ini tidak memenuhi prinsip-prinsip perkawinan yang sesuai dengan yang dilakukan oleh masyarakat pada umumnya yang biasanya diawali dengan pemilihan jodoh yang tepat, dan perkawinan harus didahului dengan peminangan dari pihak keluarga laki-laki serta didasarkan atas sukarela dan kesepakatan dari kedua belah pihak yang bersangkutan.

Penelitian ini menggunakan metode (field research) yaitu penelitian dengan cara mengamati dan meneliti keadaan yang ada di lapangan atau berada langsung pada objek penelitian ${ }^{8}$. Adapun pendekatan yang digunakan adalah pendekatan normatif ${ }^{9}$ dan sosiologi hukum. Data primer dimaksudkan untuk

\footnotetext{
${ }^{7}$ Bani Syarif Maulana, Sosiologi Hukum Islam di Indonesia, (Malang: Aditiya Media, 2010), 181.

${ }^{8}$ Sutrisno Hadi, Metodelogi Research cet I, (Yogyakarta: Andi Offset, 1995), 6.

${ }^{9}$ Penggunaan pendekatan hukum normatif diakukan dengan tujuan untuk memahami suatu proses dalam menemukan suatu aturan hukum, prinsip-prinsip hukum, maupun doktrin-doktrin hukum untuk menjawab permasalahan hukum yang dihadapi oleh masyarakat. Penelitian hukum normatif dilakukan untuk menghasilkan argumentasi, toeri atau konsep baru sebagai preskripsi dalam menyelesaiakan masalah yang dihadapi, (Peter Mahmud Marzuki). Sedangkan Pendekatan sosiologi hukum digunakan untuk mengamati apa yang menjadi karakteristik sebuah perilaku masyarakat di suatu wilayah dalam suatu aspek kehidupan sosial. Baca buku Mukti Fajar dan Yulianto Achmad, Dualisme Penelitian Hukum Normatif dan empiris, (Yogyakarta: Pustaka Pelajar, 2015), 56.
} 
memperoleh data dari informen yang ada, dikumpulkan melalui observasi, wawancara dan Dokumentasi. ${ }^{10}$

Analisis data menjadi metode yang digunakan untuk penelitian yang bersifat kualitatif dengan kerangka berfikir induktif, yaitu suatu pernyataan yang bersifat umum dan general $^{11}$. Kemudian dianalisis menggunakan perspektif sosiologi hukum yang digeneralkan pada suatu kesimpulan bersifat umum.

\section{B. PEMBAHASAN}

\section{Tradisi Perkawinan Pada Masyarakat Bima}

Suku mbojo atau yang biasa disebut dengan masyarakat Bima adalah salah satu suku yang ada di Nusa Tenggara Barat bagian timur. Suku Mbojo memiliki Beragam budaya dan tradisi, ada yang masih dilestarikan dan ada sebagian yang sudah ditinggalkan karena bertentangan dengan Agama dan prinsip masyarakatnya.

Perkawinan dalam masyarakat Bima pada umumnya dilangsungkan setelah musim panen dan juga dilakukan pada saat bulan-bulan bersejarah menurut agama Islam, seperti bulan maulid, razab dan julhijah. Pemilihan bulan-bulan tersebut dipengaruhi oleh faktor ekonomi karena bertepatan dengan musim panen. Selain bulan-bulan yang disebutkan tadi, juga ada bulan yang merupakan pantangan untuk dilangsungkan perkawinan, yaitu bulan zulkaidah. Pemilihan bulan-bulan tertentu untuk melaksanakan acara perkawinan, hanyalah karena pertimbangan akibat faktor ekonomi saja. ${ }^{12}$

Pelaksanaan dan adat istiadat pernikahan dalam adat suku Mbojo/ masyarakat Bima tidak jauh berebeda dengan daerah yang lainya. ${ }^{13}$ Pada kalangan etnis Mbojo dikenal dengan dua bentuk perkawinan yang lazim menurut istilah setempat, yakni perkawinan yang dikehendaki oleh adat dan bentuk yang menyimpang dari kehendak adat pada umumnya. Perkawinan yang diinginkan

\footnotetext{
${ }^{10}$ Afifuddin, Beni Ahmad Saebani, Metodelogi Penelitian Kualitatif, Cet. 2, (Bandung: CV, Pustaka Setia, 2012), 162.

${ }^{11}$ Imam Hafas, "Faktor Kemandulan Sebagai Alasan Poligami Menurut Hukum Islam dan Hukum Positif, Jurnal: Hukum Keluarga Jurusan Ahwal al-Syakhsiyah Fakultas Syariah IAIN Mataram, Vol. 12, No. 1 (2020), 96.

${ }^{12}$ Muhammad Fachrir Rahman, Islam di Nusa Tenggara Barat , (Mataram: ATLI, 2012), 10.

${ }^{13}$ Moh. Yamin, dan St, Rohana, Prosesi Perkawinan Adat Mbojo , ( Nusa Tenggara Barat: Dinas Kebudayaan dan Pariwisata, 2011), 11.
} 
oleh adat disebut sebagai perkawinan yang baik atau dalam bahasa bima disebut "Londo Taho". 14

Londo taho adalah perkawinan yang disepekati oleh kedua belah pihak keluarga dengan didahului adanya pinangan dari pihak laki-laki kepada orang tua si gadis melalui cara-cara yang telah ditentukan oleh adat dan diawali dengan langkah-langkah sebagai berikut: memilih jodoh, (wii nggahi), penentuan waktu acara (krawi), pengantar mahar atau (wa'a coi), dan selanjutnya (lafa) atau akad nikah. ${ }^{15}$ Itulah rangkaian kegiatan jika pernikahan dilakukan dengan cara yang baik menurut etnis mbojo yang mengacu pada syari'at Islam dan yang di kehendaki oleh adat menurut kepercayaan masyarakat Bima.

Pernikahan di masyarakat Bima tidak semua diawali dengan cara baik. Sebaian mereka melakukan pernikahan karena suatu keadaan tertentu yang tidak dikehendaki dan pernikahan tersebut dianggap meniyimpang dari kehendak adat. Seperti pernikahan dengan cara londo iha atau selarian, wa'a 'rai siwe atau melarikan gadis dengan paksa, raka mone atau mendatangi pria, dan ampa sabae.

Rangkaian pernikahan ini dianggap tidak baik, karena prosedurnya yang tidak sesaui dengan syari'at Islam. londo iha dalam tradisi masyarakat Bima dikenal dengan istilah selarian atau kawin lari. Kawin lari bagi masyarakat muslim Bima berkonotasi negatif dan ini terjadi tentu didasarkan atas faktorfaktor yang tidak diinginkan, seperti terjadinya kehamilan di luar nikah, tidak adanya persetujuan dari kedua orang tua/ pihak keluarga, kemudian adanya pemaksaan dari pihak laki-laki sehingga membawa kabur si perempuan, dan adanya permintaan menikah dari pihak perempuan atau yang biasa disebut dengan Ampa Sabae. Ampa Sabae adalah salah satu tradisi atau kebiasaan yang dilakukan oleh sebagian masyarakat Bima, sebagai upaya untuk memberikan perlindungan terhadap wanita yang telah hamil di luar nikah. ${ }^{16}$

\footnotetext{
${ }^{14}$ YS. Rachmat, Abdul Haris dan Buchari.Nika Ranako Dou Mbojo, ( Dompu : Kantor Informasi dan Komunikasi, 2009), 3.

15. M. Fachri Rahman. Pernikahan di Nusa Tenggara Barat Antara Islam dan Tradisi, (Mataram: Alam Tara Learning Instite, 2014), 10.

${ }^{16}$ Ibid, 15.
} 


\section{Ampa Sabae dalam Tradisi Perkawinan Masyarakat Muslim Desa Nipa}

\section{Kec. Ambali Kab. Bima}

\section{a. Pengertian dan Sejarah Tradisi Perkawinan Ampa Sabae}

Secara etimologi, kata ampa dan sabae teradopsi dari bahasa Bima/mbojo yaitu ampa diartikan sebagai naik, angkat atau usaha, sedangkan sabae diartikan sebagai sendiri, sebelah dan atau sepihak. ${ }^{17}$ Bagi masyarakat Bima pada umumnya dua suku kata ini sering dijadikan sebagai bahasa keseharian, kata ampa misalnya sering digabunngkan dengan kata yang lain, difungsikan sebagai kata kerja ataupun kata perintah, contonya "ampa ese uma” (naik di atas rumah), “ampa ca ese” (angkat yang tinggi), ampa kataho (angkat dngan baik), beragam makna jika digabungkan dengan suku kata yang lain. Begitupun sebaliknya dengan kata sabae. Ampa sabae dalam tradisi ini dimakani sebagai usaha atau upaya secara sepihak yang dilakukan oleh perempuan. Perempuan dalam tradisi ampa sabae menjadi pelaku utama, karena peempuan yang akan banyak berperan. ${ }^{18}$

Sejarah awal mula munculnya tradisi ampa sabae ini berdasarkan pernyataan masyarakat setempat, berawal dari kebiasaan nenek moyang yang dilakukan secara turun temurun. Ampa sabae oleh masyarakat zaman dulu dipandang sebagai bentuk perlawanan dari pihak perempuan untuk menekan tindakan pelecehan dari kaum laki-laki, karena perempuan zaman dulu sangat meyakini bahwa dengan menjaga kesucian adalah bagian dari bentuk ketaatanya kepada Allah SWT. Ketika sudah dinodai seperti itu, mereka menganggap bahwa itu merupakan dosa besar dan sudah melakukan perzinahan. Pemikiran seperti ini didasarkan pada perintah agama untuk menjaga aurat dan kesucianya sangat di ta'ati oleh perempuan pada zaman dulu.

Penjelasan terkait sejarah awal mula terbentuknya tradisi ampa sabae tersebut hanya bersumber dari mulut ke mulut, oleh karenanya penulis berasumsi bahwa sejarah tersebut masih dipertentangkan kevaliditasanya. Hal ini karena tidak adanya bukti sejarah yang dapat dipertanggungjawabkan

\footnotetext{
${ }^{17}$ Adi Sofiyan, Wawancara, (Desa Nipa, 01 April 2020)

${ }^{18}$ Henri Cembert, Bo' Sangaji Kai-Catatan Kerajaan Bima, (Bima: Yayasan Pustaka Obor Indonesia, 2013), 50.
} 
seperti dokumentasi dan sejenisnya. Namun kebiasaan pernikahan dengan cara ampa sabae memang sudah menjadi bagian dari tradisi pernikahan masyarakat Ambalawi. Ambalawi mengenal 3 (tiga) cara pernikahan yang biasa dilakukan oleh masyarakat setempat, dan cara ini sudah dilakukan secara turun temurun. Cara pertama, adalah pernikahan yang dilakukan dengan cara yang baik, yang disebut dengan londo taho oleh masyarakat Bima, pernikahan dengan cara ini yang lajim dilakukan oleh masyarakat pada umunya. Kedua, adalah dengan cara londo iha atau selarian, pernikahan seperti ini terjadi apa bila ada perselisihan yang terjadi antara kedua pihak keluarga, baik karena tidak ada persetujuan maupun karena persoalan mahar. Ketiga adalah, dengan cara ampa sabae, pernikahan yang dilakukan dengan cara ini merupakan upaya yang dilakukan oleh pihak perempuan untuk menutupi aibnya, karena merasa telah dirugikan oleh perbuatan kaum lakilaki, seperti adanya kehamilan atau pelecehan yang tidak dipertanggungjawabkan".

\section{b. Faktor dan Latar Belakang Terjadinya Perkawinan Ampa Saba}

Di bawah ini akan penulis jabarkan satu persatu latar belakang dan faktor yang mempengaruhi masyarakat Ambalawi Kabupaten Bima melakukan perkawinan dengan tradisi ampa sabe, seperti yang disampaikan oleh Bapak Ilias ${ }^{19}$ di antaranya ialah: Adanya tidakan Pelecehan, faktor Kehamilan, akibat perasaan cinta yang berlebihan, akibat ingin mempercepat pernikahan, pengaruh lingkungan/pergaulan Bebas dan faktor tidak ada persetujuan dari orang tua

Menurut Bapak Faisal salah satu tokoh masyarakat di Desa Nipa Kecamatan Ambalawi, mengatakan bahwa, "terjadinya perkawinan pada pasangan yang melakukan ampa sabae ini pada umunya berdasarkan faktor cinta, dimana antara keduanya memiliki kebebasan dalam berhubungan, karena tidak adanya pengawasan dari orang tua, sehingga terjadilah hal-hal yang tidak diinginkan, dan melanggar hukum agama, seperti halnya terjadi kehamilan di luar nikah. ${ }^{20}$

\footnotetext{
${ }^{19}$ Ilias Wawancara, (Desa Nipa, 17April 2020)

${ }^{20}$ Faisal, Wawancara, (Desa Nipa, 18 April 2020)
} 


\section{c. Prosesi dan Praktek Tradisi Ampa Sabae dalam Proses Perkawinan}

Praktek tradisi ampa sabae ini harus melalui proses panjang yang dilewati oleh pihak perempuan kepada laki-laki yang menjadi sasarannya. Sebagai jalan untuk mempermudah mendapatkan pertanggungjawaban dari pihak laki-laki maka pihak perempuan yang terlebih dahulu melaporkan perbuatan laki-laki tersebut kepada pihak-pihak yang berpengaruh di dalam desa dimana laki-laki itu tinggal. Biasanya laporan atau pengaduan dilakukan kepada tokoh masyarakat atau tokoh agama dengan maksud meminta bantuan untuk memediasikan dirinya bersama pihak keluarga laki-laki.

Berikut ini gambaran kasus ampa sabae yang terjadi pada masyarakat Ambalawi. Disini peneliti akan mengklasifikasi menjadi dua kategori, kategori pertama adalah mereka-mereka yang melakukan ampa sabae dengan alasan hamil, dan kedua karena perasaan cinta yang berlebihan.

1). Faktor Hamil

Yani dan Mustamin

Yani melakukan ampa sabae kepada Mustamin karena mustamin tidak bertanggung jawab atas kehamilanya. Yani telah hamil akibat perbuatannya dengan Mustamin. Kekhawatiran Yani terhadap kesetiaan Mustamin serta ppemikiran negatif lainnya Yani kemudian meminta bantuan Pak Sanafi untuk menyampaikan masalahnya kepada keluarga mereka. Sehingga dilakukanlah mediasi dua keluarg aoleh pak Sanafi yang akhir dari mediasi tersebut adalah keduanya dinikahkan secara ampa sabae.

2). Faktor Cinta

Evi Ratnasari dan Ihsan

Evi dan Ihsan merupakan pasangan muda yang telah berhubungan suami-istri. Meski begitu, Ihsan rupanya seringkali selingkuh. Amak Evi tidak dapat menerima perlakuan Ihsan dan ketidakyaninannya pada Ihsan untuk segera menikahinya akhirnya Evi mendatangi pak Kudus untuk melakukan ampa sabae. Evi mendatangi pak Kudus dengan membawa celana Ihsan sebagai bukti lalu kemudian keduanya menikah dengan persetujuan kedua keluarga. 
Secara keseluruhan data Pasangan Pengaten yang Melakukan Ampa Sabae di Desa Nipa Kecamatan Ambalawi Kabupaten Bima peneliti rangkum menjadi satu dalam tabel di bawah ini:

Table 6

Data pasangan penganten yang melakukan Ampa Sabae di Desa Nipa Kecamatan Ambalawi ${ }^{21}$

\begin{tabular}{|c|c|c|c|c|}
\hline & No & Nama Pasanagan & Nama Dusun & Keterangan \\
\hline \multirow{5}{*}{1} & $\mathrm{P}$ & 1. Yani dan Mustamin & Dusun Nipa 1 & Hamil \\
\hline & $\begin{array}{l}\mathrm{e} \\
1\end{array}$ & $\begin{array}{l}\text { 2. SriRahmawati } \\
\text { dan Julkifli }\end{array}$ & Dusun nipa 2 & Hamil \\
\hline & $\mathrm{a}$ & 3. Ruslin dan Junari & Harapan Baru & Hamil \\
\hline & $\begin{array}{l}\mathrm{k} \\
\mathrm{s}\end{array}$ & $\begin{array}{l}\text { 4. Bambang Irawan da } \\
\text { Nurwahida }\end{array}$ & Ujung Harapan & Hamil \\
\hline & $\mathrm{a}$ & 5. Irfan dan Marma & Dana Bura & Hamil \\
\hline \multirow[t]{3}{*}{2} & $\begin{array}{l}\mathrm{n} \\
\mathrm{a}\end{array}$ & $\begin{array}{l}\text { 6.Ferdian dan } \\
\text { Nuraini }\end{array}$ & Nanga Raba & Hamil \\
\hline & $\mathrm{a}$ & 7. Sofian dan Narti & Nanga Raba & Hamil \\
\hline & $\begin{array}{l}\mathrm{p} \\
\mathrm{e}\end{array}$ & 8. Evi Ratnasari dan Ihsan & Ujung Kalate & Cinta \\
\hline
\end{tabular}

r

$\mathrm{k}$

awinan melalui ampa sabae seperti pelaksanaan perkawinan pada umunya, namun perbedaannya adalah alasan atau latar belakang terjadinya perkawinan tersebut. Setiap pelaku ampa sabae ini tetap akan dinikahkan secara tercatat namun proses awalnya saja yang dilakukan secara adat. Mengingat kondisi atau keadaan yang sangat tidak memungkinkan dimana kehamilan adalah

${ }^{21}$ Observasi Desa Nipa Kecamatan Ambalawi, Tanggal 06 Mei 2020. 
sebagai alasanya, maka perkawinan pun harus dilaksanakan dengan cepat, karena apabila tidak dilaksanakan aib perempuan yang hamil tersebut akan menyebar dan merusak moral masyarakat. Kejadian ini juga dikhawatirkan akan berdampak pada kondisi psikologi si perempuan itu sendiri, akibat dipengaruhi oleh rasa malunya dia bisa saja melakukan hal-hal yang bisa merugikan dirinya sendiri, seperti melakukan bunuh diri, aborsi dan mengkomsumsi obat-obat terlarang untuk menenangkan dirinya.

\section{d. Pandangan Masyarakat Terhadap Tradisi Perkawinan Ampa Sabae}

Ampa sabae merupakan adat atau tradisi masyarakat Desa Nipa Kecamatan Ambalawi yang diwariskan oleh nenek moyangnya kepada kegenerasi berikutnya yang hingga saat inipun masih dipraktikan. Dari segi praktik-nya tradisi ampa sabae saat ini banyak dilakukan oleh perempuan yang telah hamil di luar nikah. Sehingga lambat laun tradisi ini dikenal sebagai kebiasaan negatif oleh masyarakat. Masyarakat menganggap bahwa kehamilan yang terjadi pada perempuan tersebut menjadi sebuah bukti bahwa dirinya telah melakukan perzinahan terlebih dahulu dengan laki-laki.

Seiring dengan perkembangan masa dan proses berfikir masyarakat Bima, adat ini menimbulkan perdebatan diantara masyarakat yang satu dengan dengan masyarakat yang lainya. Sehingga akibat dari perdebatan yang pelik ini melahirkan golongan yang pro dan golongan yang kontra terhadap eksistensi tradisi tersebut.

Golongan yang pro adalah didominasi oleh kalangan tertua dalam masyarakat. Mereka mengatakan bahwa tradisi ampa sabae merupakan warisan leluhur yang harus dilestarikan. Masyarakat tertua Bima mempunyai keyakinan yang kuat bahwa setiap yang dibawa oleh nenak moyang atau leleuhur akan memberikan dampak yang baik bagi anak cucunya. Pelestarian tradisi ini juga dengan maksud untuk mengantisipasi munculnya kasus yang sama yang akan menimpa kaum perempuan lainya. Tradisi ampa sabae sebenarnya bagian dari solusi untuk mempermudah penyelesaian permasalahan yang dihadapi oleh perempuan.

Sedangkan bagi golongan yang kontra menilai ampa sabae sebagai tradisi yang tidak dikehendaki oleh adat dan tidak sesuai prinsip Islam sebab ampa 
sabae merupakan permintaan menikah dari perempuan kepada laki-laki dengan alasan tertentu yang tidak berdasarkan pada kesepakatan bersama malinkan keinginan sendiri, tradisi ini dianggap tidak elok "kurang bagus" karena adat pernikahan yang benar yang sesuai dengan syariat islam. Artinya izin menikah harus diminta secara baik-baik oleh puhak laki-laki dengan menghitbah atau melamar bukan dengan cara ampa sabae atau londo iha.

Pernikahan melalui ampa sabae merupakan kondisi pernikahan yang di dalamnya ada aib yang harus dijaga oleh perempuan, karena mengkhawatirkan aib itu terbongkar dan menjadi perbincangan masyarakat, lalu si perempuan mempercepat proses pernikahan dengan melakukan ampa sabae untuk meminta pertanggungjawaban kepada laki-laki yang telah menghamilinya. Meskipun prosesnya diselesaikan secara musawarah dan mufakat oleh tokoh masyarakatnya dan tokoh adat secara baik-baik, tetap saja pernikahannya nanti dianggap aib oleh masyarakat luas dan si pelaku menjadi bahan pembicaraan yang negatif oleh masyarakat terutama ibu-ibu, pada dasarnya pernikahan dengan cara ampa sabae berkonotasi negatif, karena setiap ada perempuan yang meminta untuk dinikahkan pasti sudah dalam keadaan hamil. ${ }^{22}$

Namun faktanya Sampai sekarang tradisi ampa sabae masih dijadikan sebagai adat istiadat dalam proses perkawinan masyarakat muslim di Desa Nipa, karena memang sampai detik ini masih ada yang memanfaatkanya untuk kepentingan individu-individu yang membutuhkan, sepertihalnya perempuan. Tradisi ini dibiarkan dengan alasan sebagai kemaslahatan apabila muncul suatu problem pada masyarakat itu sendiri terutama bagi perempuan. Dalam masyarakat tradisi ini diyakini dapat membantu dan dijadikan sebagai solusi.

Tokoh agama Bapak Mustawa ${ }^{23}$ sebagai penyuluh agama dan Ketuan KUA kecamatan Ambalawi mengatakan bahwa pernikahan melalui tradisi ampa sabae dianggap sebagai perbuatan yang "darurat", dimana dalam Islam sendiri memperbolehkan seseorang untuk melakukan perbuatan yang diharamkan jika itu dalam kondisi darurat. Perempuan meminta menikah nentu dengan alasan yang darurat, sehingga tokoh adat dan tokoh agama membantu mempercepat prosesnya. Setiap adat istiadat yang terjadi pada masyarakat

\footnotetext{
${ }^{22}$ Bapak Gunawan, Wawancara, (Desa Nipa, 10 Mei 2020)

${ }^{23}$ Bapak Mustawa, Wawancara, (Desa Ambalawi, 10 Mei 2020))
} 
tidak menjadi persoalan selama perbuatan itu masih memberikan kemaslahatan bagi masyarakat.

\section{Analisis Terhadap Latar Belakang Munculnya Tradisi Ampa Sabae dalam} Proses Perkawinan Masyarakat Muslim di Desa Nipa Kec. Ambalawi Kab. Bima

Sebagai usaha untuk mempermudah peneliti menganalisis permasalahan yang ada dalam penulisan ini peneliti menggunakan teori Konstruksi sosial ${ }^{24}$ dari Peter L. Berger dan Thomas Lucman, dalam bukunya yang berjudul The Social Conduction of Reality: A treatise in the Sociological of Knowledge (1966). Ia menggambarkan proses sosial melalui tindakan dan interaksinya, dimana individu menciptakan secara terus-menerus suatu realitas yang dimiliki dan dialami bersama secara subyektif ${ }^{25}$. Ketika suatu peristiwa itu dilakukan secara berulang-ulang dengan tujuan yang sama maka akan menghasilkan sistem nilai dan keyakinan. Keyakinan tersebut kemudian dijadikan sebagai sebuah pertauran yang harus di taati bersama oleh masyarakat setempat ${ }^{26}$. Begitupun dengan tradisi ampa sabae. Selain teori konstruksi sosial peneliti juga menggunakan teori feminisme yang dicetuskan oleh Betty Friedan pada Tahun 1963, dan The Second Sex, yang di tulis oleh Beauvior yang menjadi landasan gerakan feminise gelombang kedua. ${ }^{27}$

Teori feminisme merupakan generalisasi sistem ide tentang kehidupan sosial dan pengalaman manusia yang dikembangkan dari perspektif perempuan. Perspektif perempuan dalam teori feminisme yang bertujuan untuk memperjuangkan hak-hak kaum perempuan sebagai kelas sosial. ${ }^{28}$ Sebagai pusat , situasi dan pengalaman sosial yang ditangkap selalu merujuk pada sudut

24 Teori kontstruksi sosial melihat realitas dalam sistem sosial yang diciptakan melalui interaksi timbal balik sehingga menghasilkan sisitem nilai dan yekainan. Sistem nilai dan keyakinan tersebut dipraktikan dan diperankan berulang-ulang oleh masyarakat yang akhirnya melekat dalam sistem yang kemudian dianggap sebagai realitas, lebih lanjut lihat di sosiologi.com (teori-teori sosiologi)

${ }^{25}$ M. Burhan Bungin, Konstruksi Sosial Media Masa, (Jakarta: Pernadamedia Group, 2015), 13

${ }^{26}$ Zainuddin, “ Teori Konstruksi Sosial”, dalam http://Zainuddin. Lecturer.Uin-malang.ac.id. diambil tanggal, 02 Mei 2018, Pukul 10.50 Wita

27 Sindung Haryanto, Spektrum Teori Sosial, Dari Klasik Hingga Poestmoderen, (Jogjakarta: AR-Ruzz Media, 2012), 100.

${ }^{28}$ Muzakki, Ahmad. 2017. "Kafaah Dalam Pernikahan Endogami Pada Komunitas Arab Di Kraksaan Probolinggo". Istidlal: Jurnal Ekonomi Dan Hukum Islam 1 (1), 19. 
pandang perempuan. Perkembangan teori feminis yang berangkat dari perlunya melihat perspektif perempuan didasarkan pada asumsi bahwa pengetahuan tentang dunia yang berkembang selama ini cenderung memarjinalkan perspektif perempuan. $^{29}$

Pemosisian subordinat perempuan dalam diskursus sosial, budaya, politik, ekonomi dan filsafat mengakibatkan terpinggirkanya perempuan dalam praktik. Akhirnya muncul dominasi, hegomoni, diskriminasi terhadap kaum perempuan. Teori feminisme sebagai teori sosiologi menantang sitem dominasi yang memarjinalkan kaum perempuan. Teori ini merupakan perjuangan dari gerakan feminisme untuk mencari keseimbangan gender. Gerakan ini dilakukan untuk membebaskan perempuan dari rasisme, stereotyping, seksisme, dan penindasan terhadap perempuan. ${ }^{30}$

Setiap tinadakan manusia baik itu tindakan yang positif maupun negatif, baik tindakan itu memberikan kebahagiaan ataupun tidak, dan baik memberikan ketenangan bagi manusia atau tidak. Semua itu tidak terlepas dari dari faktorfaktor penyebabnya. Demikian halnya dengan latar belakang munculnya tradisi ampa sabae yang dilestarikan oleh masyarakat Desa Nipa Kecamatan Ambalawi Kabupaten Bima.

Tradisi ampa sabae, atau permintaan menikah oleh perempuan merupakan sebuah adat kebiasaan yang sudah dilakukan oleh masyarakat sejak lama secara turun temurun, jadi untuk mengetahui siapa yang menjadi pelaku dibalik sejarah terbentuknya tradisi ini masyarakat setempat tidak mengetahuinya secara pasti, namun mereka meyakini bahwa ini merupakan warisan dari tradisi nenek moyang mereka.

Tradisi ampa sabae oleh masyarakat zaman dulu dipandang sebagai bentuk perlawanan dari pihak perempuan untuk menekan tindakan pelecehan dari kaum laki-laki. Bahkan ketika sarung atau jilbab perempuan ditarik hal ini sudah dinanggap pelecehan. Kasus pelecehan terhadap perempuan masih mengangkar dalam kehidupan masyarakat, ini dipengaruhi oleh gaya hidup budaya

\footnotetext{
${ }^{29}$ Syarifudin Jurdi, Sosiologi Nusantara Memahami Sosiologi Integralistik, (Jakarta: Kencana Prenadamedia Group, 2013), hlm,270.Betty Friedan, pada tahun 1963

${ }^{30}$ https:// Relasigender blog. Wordpress.Com ,Teori- Teori Feminisme, diambil tanggal 02 Mei 2020, Pukul 09.00 Wita.
} 
patriarkhi $^{31}$ yang masih mendarah daging dalam sistem tatanan kehidupan masyarakat zaman dulu.

Budaya patriarki memposisikan laki-laki sebagai pihak yang gagah dan cenderung memiliki keleluasaan untuk melakukan apapun terhadap perempuan. Sikap budaya yang seperti ini kemudian menyebabkan tingginya angka pelecehan seksual di Indonesia. Budaya ini juga memberikan konstruksi dan pola pikir apabila laki-laki berkaitan erat dengan ego maskulinitasnya, sementara feminisme sendiri diabaikan dan dianggap sebagai suatu yang lemah. Masyarakat seperti membiarkan jika ada laki-laki bersiul dan menggoda kaum perempuan yang melintas di jalan. Tindakan laki-laki yang melecehkan perempuan dengan cara seperti itu seolah-olah menjadi hal yang lumrah dan wajar. $^{32}$

Berangkat dari fenomena kehidupan dalam budaya patriarki tersebut, lalu muncul sebuah perubahan baru dalam kehidupan masyarakat, dimana perempuan-perempuan sudah diberikan kebebasan untuk meperjuangkan hakhaknya dan menuntut untuk mendapatkan kesetraan hak yang sama dengan lakilaki. ${ }^{33}$ Munculnya teori feminisme menunjukan bahwa perempuan dalam kehidupan masyarakat memang cenderung diabaikan keberadaan dan kemampuanya, perempuan sering mendapat perlakuan yang tidak baik dari lingkunganya, kekerasan dan pelecehan seksual yang terus menerus terjadi dalam lingkungan sosial menjadi ancaman besar.

Perempuan ketika sudah dilecehkan, maka harga dirinya sudah tidak ada lagi. Ketika perempuan tidak bisa langsung mendapatkan pertanggungjawaban, maka perempuan mengupayakan berbagai macam cara. Seperti halnya dengan

31 Budaya patriarki masih mendominasi aktivitas domestik, ekonomi, politik, dan budaya. Sehingga hasil dari parktik budaya tersebut menyebabkan berbagai masalah sosial di masyarakat. masalah sosial adalah suatu kondisi yang tidak diinginkan terjadi oleh sebagian besar dari masyarakat seperti kehadiran budaya patriarki ini melahirkan tindakan kekerasan, pelecehan seksual dan penelantaran terhadap perempuan. Dampak dari budaya patriarki di Indonesia masuk ke dalam system blame approach, yaitu permasalahan yang diakibatkan oleh sistem yang berjalan tidak sesuai dengan keinginan atau harapan. Kekerasan, pelecehan, dan penelantaran dalam masyarakat terjadi akibat adanya sistem budaya yang memiliki kecendrungan untuk memperbolehkan itu terjadi kepada perempuan. Lebih lengkap lihat Jurnal Ade Irma Sakina dan Dessy Hasanah Siti A, "Menyoroti Budaya Patriarki di Indonesia", social work Jurnal, Vol. 7, No. 1 (2017), 72.

${ }^{32}$ Ibid, 74.

${ }^{33}$ Syarifudin Jurdi, Sosiologi Nusantara Memahami Sosiologi Intergralistik, (Jakarta: Kencana Prenada Media, 2013), 270. 
cara melakukan tradisi ampa sabae, dengan tradisi ini akan mempermudah jalan kaum perempuan untuk menuntut dan meminta pertanggungjawaban. Dalam tradisi ampa sabae perempuan sengaja di berikan hak untuk menuntut pertanggungjawaban dari laki-laki ketika mendapatkan perlakuan yang tidak senonoh.

Lambat laun tradisi ini dikenal sebagai kebiasaan negatif oleh masyarakat, karena pelakunya adalah wanita yang hamil di luar nikah saja, dimana dalam pandangan masyarakat menganggap bahwa kehamilanya itu menjadi sebuah bukti bahwa dirinya telah melakukan perzinahan terlebih dahulu. Jauh berbeda dari jaman dulu yang menganggap tradisis ini sebagai suatu kebaikan yang tidak merusak moral dan martabat pelakunya.

Dalam penyelesaian perkara ini masyarakat tetap tidak bisa terlepas dari adat istiadat setempat. Hubungan di luar nikah ini merupakan penyakit sosial yang sulit untuk dihilangkan dan itu merupakan aib dan masalah besar dalam masyarakat. Sebagai jalan untuk menutup aib tersebut maka masyarakat mengupayakan berbagai macam cara, seperti halnya melakukan perkawinan dengan cara ampa sabae sebagai jalan keluar jika laki-laki tidak mau bertanggung jawab atas perbuatanya. Masyarakat Ambalawi mengatakan tradisi ini tidak bertentangan dengan syari'at Islam karena dalam Islam juga memperbolehkan wanita hamil menikah, baik dengan laki-laki yang telah menghamilinya maupun dengan laki-laki yang tidak menghamilinya, atas dasar sukarela dan kesepakatan bersama.

Sebagaimana dijelaskan dalam Kompilasi Hukum Islam (KHI) pasal 53, perkawinan untuk wanita hamil di luar nikah bisa dilaksanakan atau dapat dikawinkan dengan pria yang menghamilinya, perkawinan dapat dilangsungkan tanpa menunggu terlebih dahulu kelahirana anaknya dan dengan dilangsungkanya perkawinan pada saat wanita hamil, tidak diperlukan lagi perkawinan ulang setelah anak yang dikandung lahir. Hal senada juga yang menjadi dasar masyarakat Ambalawi melakukan pratek tradsis ampa sabae, kepada perempuan yang telah hamil di luar nikah, untuk menyelamatkan nasab 
anaknya serta melindungi aib keluarganya. ${ }^{34}$ Tradisi yang berkembang dalam kehidupan masyarakat Ambalawi pada saat ini, merupakan suatu tindakan masyarakat yang bertujuan untuk kemaslahatan, sehingga eksistensinya masih di biarkan dan diberlakukan tanpa ada upaya untuk menghilangkanya.

Hemat peniliti menyimpulkan bahwa tradisi ampa sabe yang dilakukan oleh masyarakat Bima tersebut merupakan bagian dari proses sosial yang timbul akibat tindakan dan interaksi masyarakat itu sendiri. Tradisi tersebut kemudian masuk kedalam individu-individu melalui proses internalisasi yang dipraktikan berulang-ulang dengan proses yang disebut ekstralisasi hingga melekat dalam institusi sistem sosial. Realitas tersebut dianggap sudah demikian adanya padahal itu diciptakan.

4. Analisis Pandangan Sosiologi Hukum Terhadap Tradisi Ampa Sabae dalam Proses Perkawinan Masyarakat Muslim di Desa Nipa Kec. Ambalawi Kab. Bima

Dalam sosiologi hukum yang menjadi pembahasan adalah pengaruh timbal balik antara perubahan hukum dan masyarakat. Perubahan hukum dapat mempengaruhi perubahan masyarakat, dan sebaliknya perubahan masyarakat dapat menyebabkan terjadinya perubahan hukum. ${ }^{35}$ Perubahan sosial adalah suatu proses yang dilakukan oleh masyarakat sehingga menjadi berbeda dengan sebelumnya. Kingley Davis mengatakan hal yang sama bahwa perubahan sosial adalah perubahan-perubahan yang terjadi dalam struktur dan fungsi masyarakat ${ }^{36}$.

Berdasarkan definisi tersebut sisologi adalah suatu ilmu yang menggambarkan tentang keadaan masyarakat lengkap dengan stuktur lapisan serta berbagai gejala sosial lainya yang saling berkaitan. Oleh karena itu, sosiologi dapat dugunakan sebagai salah satu pendekatan serta kajian dalam memahami suatu fenomena atau tradisi. Seperti halnya dengan fenomena tradisi ampa sabae yang dilakukan oleh masyarakat Ambalawi.

${ }^{34}$ Imam Syafi'i. "Konsep Kafaah Dan Keluarga Sakinah (Studi Analisis Tentang Korelasi Hak Kafa'ah Terhadap Pembentukan Keluarga Sakinah)". Asy-Syari'ah: Jurnal Hukum Islam 6, no. 1 (15 Februari 2020): 33.

${ }^{35}$ Soerjono Soekanto, sosiologi suatu pengantar cet. Ke-43, (Jakarta: PT Raja Grafindo Persada, 2020), 12.

${ }^{36}$ Mudjita Raharjo, "perubahan Sosial di Mintakat Panglaju Bandung Malang”, Jurnal STAIN Malang, edisi No. 5, 1998, 7, 5. 
Tradisi ampa sabae merupakan fenomena sisoal yang terjadi pada wilayah perkawinan adat, yang di dalam prakteknya melibatkan beberapa komponen masyarakat (keluarga), seperti pelaku, orang tua pelaku, tokoh agama dan tokoh masyarakat. peneliti katakan peristiwa ini sebagai fenomena sosial karena pada tataran implementasinya, tradisi ampa sabae selain menimbulkan ketegangan sosial di antara kedua belah pihak keluarga pelaku, juga menimbulkan perdebatan mendalam dari segi nilai dikalangan masyarakatnya, sebagaiman penulis jelaskan pada pembahasan sebelumnya.

Setiap individu atau kelompok memiliki pandangan yang berbeda terkait hal yang sama, tetapi dari sudut pandangan yang berbeda ada suatu hal yang memang menjadi dasar bagaimana sebuah pemikiran itu timbul, sehingga diperlukannya aturan-aturan dan batasan-batasan yang dapat menciptakan kepastian hukum yang sesuai kebutuhan masyarakat. Terjadinya suatu perubahan dalam tradisi mampu merubah pola pikir masyarakat, seperti halnya yang telah dijelaskan oleh Soerjono Soekanto ${ }^{37}$ bahwa perubahan sosial yang tidak dikehendaki atau tidak direncanakan merupakan perubahan-perubahan yang terjadi tanpa dikehendaki, berlangsung di luar jangkuan pengawasan masyarakat dan dapat menyebabkan timbulnya akibat-akibat sosial yang tidak diharapkan oleh masyarakat.

Perubahan yang terjadi dalam masyarakat mempunyai faktor-faktor yang menjadi pendorong perubahannya. Pola-pola perilaku masyarakat sangat dipengaruhi oleh kebudayaan yang ada dalam masyarakat itu sendiri. Pola perilaku berbeda dengan kebiasaan, dimana kebiasaan merupakan cara bertindak seorang anggota masyarakat yang kemudian diakui dan mungkin diikuti oleh orang lain ${ }^{38}$.

Akibat adanya unsur kehamilan dibalik alasan tradisi ampa sabe tersebut kemudian merubah pola mikir masyarakat yang awalnya berpikir positif tentang tradisi ampa sabae, menjadi negatif karena adanya faktor kehamilan dari perempuan. Masyarakat berpikir bahwa laki-laki dan perempuan tersebut sudah melakukan perzinahan terlebih dahulu sebelum adanya ikatan yang sah, dan dalam agama perzinahan itu merupakan perbuatan dosa. Islam sangat melarang

\footnotetext{
${ }^{37}$ Soerjono Soekanto dan Budi Sulistiyowati, Sosiologi...159.

${ }^{38}$ Soerjono Soekanto dan Budi Sulistyowati, Sosiologi,... 157.
} 
suatu pergaulan antra seorang laki-laki dan seorang perempuan tanpa melalui pintu perkawinan yang sah.

Meskipun pada umumnya mereka memberikan argument seperti itu, namun pihak masyarakat, tokoh agama, dan pemerintah desa sama sekali tidak memberikan sangsi yang berat secara hukum pidana. Ampa sabae oleh sebagian masyarakat hanya dipandang sebagai tindakan yang merusak moral dan citra sosial keluarga, baik status sosial keluarga laki-laki maupun perempuan.

Pada saat peneliti melakukan observasi lebih lajut lagi ternyata tidak semua masyarakat yang ada dilingkungan Desa Nipa memandang tradisi ini sebagai bentuk dari tindakan yang merusak moral, ada juga yang memandang perkawinan dengan cara seperti ini sebagai bentuk kebaikan bagi perempuan, supaya bisa terhindar dari fitnah dan mendapatkan pernikahan yang sah dari laki-laki yang telah menodainya.

Beragam pernyataan tersebut, tidak menjadi penghalang bagi keseluruhan masyarakat Desa Nipa Kecamatan Ambalawi Kabupaten Bima untuk melestarikan salah satu tradisi pernikahan yang sudah diyakini sejak lama ini, secara keseluruhan masyarakat Ambalawi tetap mengakui serta meyakini eksistensi dan keberadaan tradisi ini sebagai bentuk warisan dari nenek moyang terdahulu, dibuktikan dengan sampai detik ini masih ada sebagian masyarakat yang memanfaatkanya. Namun yang menjadi permasalahanya yaitu timbulnya pro dan kontra dari praktek tradisi itu sendiri, karena secara garis besar masyarakat menegetahui latar belakang dibalik munculnya tradisi ini akibat karna adanya kehamilan di luar pernikahan.

Berdasarkan realitas tersebut lalu dikaitkan dengan pendapat Max Weber, yang melihat realitas sosial sebagai perilaku sosial yang memiliki makna subyektif, karena itu perilaku memiliki tujuan dan motivasi. Perilaku sosial itu menjadi 'sosial' oleh Weber dikatakan jika yang dimaksud subyektif dari perilaku sosial itu membuat individu mengarahkan dan memperhintungkan kelakuan orang lain dan mengarahkan kepada subjektif. Perilaku itu memiliki 
kepastian kalau menunjukan keseragaman dengan perilaku pada umunya dalam masyarakat. $^{39}$

Berger dan Luckman, mengatakan institusi masyarakat tercipta dan dipertahankan atau diubah melalui tindakan dan interaksi manusia. Karena setiap masyarakat memiliki sistem pengetahuan yang diterima secara turun temurun . Seperti halnya mitos, takhayul, pamali, prewengan atau yang lainya, tetapi jelas masyarakat itu sendiri yang menciptakan, mengembangkan dan memodifikasikanya. ${ }^{40}$

Pernyataan ini selaras dengan fenomena yang terjadi dalam kehidupan masyarakat Ambalawi, dimana untuk menyingkapi sebuah peristiwa yang terjadi dalam lingkunganya selalu diarahkan dan diperhintungkan berdasarkan tindakan individu itu sendiri, seperti halnya perubahan pemahaman tentang makna dari tradisi ampa sabae itu sendiri. Akibat adanya perempuan yang melakukan ampa sabae dengan alasan hamil, lalu merubah pola pikir masyarakat sehingga menimbulkan pandangan negatif, tanpa menyadari lagi tujuan dibalik tradisi itu terbentuk bardasarkan kepentingan mayoritasnya.

Selo Sumarjan ${ }^{41}$ mendefinisikan perubahan sosial adalah segala perubahan pada lembaga-lembaga kemasyarakatan di dalam suatu masyarakat yang mempengaruhi sistem sosialnya, termasuk di dalamnya nilai-nilai, sikap-sikap dan pola-pola perilaku di antara kelompok-kelompok dalam masyarakat ${ }^{42}$. Perubahan sosial di atas memberi isyarat bahwa perubahan sosial terlihat atau diperlihatkan oleh adanya suatu reaksi terhadap adanya tuntutan aktivitas dalam situasi yang baru dan menghasilkan perubahan, baik perubahan dalam bentuk sistem sosialnya maupun fungsi sosialnya. ${ }^{43}$

${ }^{39}$ Burhan Bungin, Konstruksi Sosial Media Massa, (Jakarta: Pernadamedia Group, 2015), 12.

${ }^{40} \mathrm{Ibid}, \mathrm{hlm}, 17$.

41 Selo Soemardjan, Perubahan Sosial di Yogyakarta (Yogyakarta: Gadjah Mada University Press, 1986), 303

43 Diambil di https//www-kelaspintar-id.cdn.ampproject.org, Hari minggu Tanggal 10 Oktober 2020, pukul 09: 00 WIB. 


\section{KESIMPULAN}

Latar belakang munculnya tradisi ampa sabae dalam proses perkawinan masyarakat muslim di Desa Nipa Kecamatan Ambalawi Kabupaten Bima, berawal dari kebiasaan nenek moyang yang diwariskan secara turun temurun. Ampa sabae pada masyarakat zaman dulu dilakukan bukan karena faktor hamil saja, melainkan karena hal-hal sepele yang mereka anggap sebagai pelecehan, seperti ditarik oleh laki-laki sarungnya, ataupun dipegang tanganya, hal ini oleh perempuan zaman dulu bisa dijadikan alasan untuk melakukan ampa sabae. Berdasarkan perspektif masyarakat terjadi pro dan kontra di anatara mereka dalam menilai tradisi perkawinan dengan cara ampa sabae ini, perbedaan pandangan tersebut tidak membatasi eksistensi tradisi ini dalam kehidupan masyarakat, terlihat samapai sekarang masih dilestarikan dan tidak ada upaya dari masyarakat untuk menghilangkanya. Tradisi ini dijadikan sebagai kemaslahatan dan solusi bagi perempuan apabila perempuan dihadapkan dengan kondisi ketidakadilan. 


\section{DAFTAR PUSTAKA}

Afifuddin, Beni Ahmad Saebani, Metodotologi Penelitian Kualitatif, Cet.2, Bandung: CV. Pustaka Setia, 2012.

Bungin Burhan, Konstruksi Sosial Media Massa, Jakarta: Pernadamedia Group, 2015.

Cembert Henri, Bo' Sangaji Kai-Catatan Kerajaan Bima, (Bima: Yayasan Pustaka Obor Indonesia, 2011.

Fajar Mukti dan Achmad Yulianto, Dualisme Penelitian Hukum Normatif dan empiris, Yogyakarta: Pustaka Pelajar, 2015.

Hadi Sutrisno, Metodelogi Research cet I, Yogyakarta: Andi Offset, 1995.

Hafas Imam,"Faktor Kemandulan Sebagai Alasan Poligami Menurut Hukum

Islam dan Hukum Positif, Jurnal: Hukum Keluarga Jurusan Ahwal alSyakhsiyah Fakultas Syariah IAIN Mataram, Vol. 12, No. 1 (2020).

https//www-kelaspintar-id.cdn.ampproject.org,

https:// Relasigender blog. Wordpress.Com ,Teori- Teori Feminisme,

https://www.scribd/doc/308373305/teori- kontruksi-sosial-Peter L Berger

Imam Syafi'i. "Konsep Kafaah Dan Keluarga Sakinah (Studi Analisis Tentang Korelasi Hak Kafa'ah Terhadap Pembentukan Keluarga Sakinah)”. Asy-Syari'ah: Jurnal Hukum Islam 6, no. 1 (15 Februari 2020).

Jurdi Syarifudin, Sosiologi Nusantara Memahami Sosiologi Integralistik, Jakarta: Kencana Prenadamedia Group, 2013.

Jurdi YS , Haris Abdul dan Buchari.Nika Ranako Dou Mbojo, Dompu : Kantor Informasi dan Komunikasi, 2009.

Kontjaraninggrat, Kebudayaan Jawa Jakarta: Balai Pustaka, 1984.

Maulana Bani Syarif, Sosiologi Hukum Islam di Indonesia, Malang: Aditiya Media, 2010.

Maulana Bani Syarif, Sosiologi Hukum Islam di Indonesia, Malang: Aditiya Media, 2010. 
Muzakki, Ahmad. 2017. "Kafaah Dalam Pernikahan Endogami Pada Komunitas Arab Di Kraksaan Probolinggo”. Istidlal: Jurnal Ekonomi Dan Hukum Islam 1 (1).

Pattiroy Ahmad dan Salam Idrus, “Tradisi Doi 'Menre' dalam Pernikahan Adat Bugis Jambi”, Jurna: Al-Ahwal, Vol. 1, No, 1 (2008).

Rahman M. Fachri. Pernikahan di Nusa Tenggara Barat Antara Islam dan Tradisi, Mataram: Alam Tara Learning Instite, 2014.

Rahman Muhammad fachrir, Islam di Nusa Tenggara Barat, Mataram: ATLI, 2012.

Ramdan Wagianto, "Tradisi Kawin Colong Pada Masyarakat Osing Banyuwangi Perspektif Sosiologi Hukum Islam”, Jurnal Al-Ahwal, Vol. 10, No. 1, 2017. Sainun, Tradisi Merari', Mataram: IAIN Matram, 2016.

Sakina Ade Irma dan Siti A Dessy Hasanah, "Menyoroti Budaya Patriarki di Indonesia", Jurnal: social work, Vol. 7, No. 1 (2017).

Santoso Imam Budhi, Petuah-Petuah Bijak Para Leluhur Seputar Perkawinan, Yogyakarta: Laksana, 2011.

Soemardjan Selo, Perubahan Sosial di Yogyakarta, Yogyakarta: Gadjah Mada University Press, 1986.

Soemardjan Sindung, Spektrum Teori Sosial, Dari Klasik Hingga Poestmoderen, Jogjakarta: AR-Ruzz Media, 2012.

Soemardjan Soerjono, sosiologi suatu pengantar cet. Ke-43, Jakarta: PT Raja Grafindo Persada, 2020.

Sugiyono, Metode Penelitian Kualitatif, Jakarta: PT. Raja Grafindo Persada, 2001.

Undang-Undang No 1 Tahun 1974 tentang Perkawinan.

Yamin Moh., dan Rohana St, Prosesi Perkawinan Adat Mbojo, Nusa Tenggara Barat: Dinas Kebudayaan dan Pariwisata, 2011.

Zainuddin, “ Teori Konstruksi Sosial”, dalam http: / / Zainuddin. Lecturer.Uinmalang.ac.id. 